\title{
ISOTOPE DETERMINATION OF SULFUR BY MASS SPECTROMETRY IN SOIL SAMPLES ${ }^{(1)}$
}

\author{
Alexssandra Luiza Rodrigues Molina Rossete ${ }^{(2)}$,J osiane Meire Toloti Carneiro ${ }^{(2)}$, Carlos \\ Roberto Sant Ana Filho(2) \& J osé Albertino Bendassolli( ${ }^{(3)}$
}

\begin{abstract}
SUMMARY
Sulphur plays an essential role in plants and is one of the main nutrients in several metabolic processes. It has four stable isotopes $\left({ }^{32} \mathrm{~S},{ }^{33} \mathrm{~S},{ }^{34} \mathrm{~S}\right.$, and ${ }^{36} \mathrm{~S}$ ) with a natural abundance of $95.00,0.76,4.22$, and 0.014 in atom \%, respectively. A method for isotopic determination of S by isotope-ratio mass spectrometry (IRMS) in soil samples is proposed. The procedure involves the oxidation of organic $S$ to sulphate $\left(\mathrm{S}^{-} \mathrm{SO}_{4}{ }^{2-}\right)$, which was determined by dry combustion with alkaline oxidizing agents. The total $\mathrm{S}-\mathrm{SO}_{4}{ }^{2-}$ - concentration was determined by turbidi metry and the results showed that the conversion process was adequate. To produce gaseous $\mathrm{SO}_{2}$ gas, $\mathrm{BaSO}_{4}$ was thermally decomposed in a vacuum system at $900{ }^{\circ} \mathrm{C}$ in the presence of $\mathrm{NaPO}_{3}$. The isotope determination of $\mathrm{S}$ (atom $\%^{34} \mathrm{~S}$ atoms) was carried out by isotope ratio mass spectrometry (IRMS). In this work, the labeled material $\left(\mathrm{K}_{2}{ }^{34} \mathrm{SO}_{4}\right)$ was used to validate the method of isotopic determination of $\mathrm{S}$; the results were precise and accurate, showing the viability of the proposed method.
\end{abstract}

Index terms: sample preparation, soil samples, isotopic di lution, labeled material, stable isotope, 34 S.

\section{RESUMO:DETERMINAÇÃOISOTÓPICA DE ENXOFRE POR ESPECTROMETRIA DE MASSAS (IRMS) EM AMOSTRAS DE SOLO}

O enxofretem papel essencial em plantas, sendoum dos principais nutrientes em diversos processos metabólicos; ele apresenta quatro isótopos estáveis (32S, ${ }^{33} \mathrm{~S},{ }^{34} \mathrm{~S}$ e ${ }^{36} \mathrm{~S}$ ), com abundância natural de95,00, 0,76, 4,22 e0,014 \% em átomos, respectivamente Desenvolver

(1) Part of the first author's doctoral dissertation, presented to the Graduate Program in Science, Centro de Energia Nuclear na Agricultura - CENA/USP. Study funded by FAPESP. Received for publication in October 26, 2011 and approved in Sptember, 13,2012

(2) Post-Doctoral Program in Science at Centro de Energia Nuclear na Agricultura - CENA/USP. Caixa Postal 96. CEP 13416-000 Piracicaba (SP), Brazil.E-mail: al rossete@hotmail.com; josiane@cena.usp.br; santana@cena.usp.br

(3) Associate Professor, Centro de Energia Nuclear na Agricultura - CENA/USP. E-mail: jab@cena.usp.br 


\begin{abstract}
um método para determi nação isotópica doS por espectrometria demassas derazãoisotópica (IRMS) em amostras de sol o foi o objetivo destetrabal ho. A oxi dação deS orgânico a sul fato $\left(\mathrm{S}-\mathrm{SO}_{4}{ }^{2-}\right)$ foi avaliada utilizando a oxi dação via seca com agentes oxidantes alcalinos. A concentraçãoS $-\mathrm{SO}_{4}{ }_{4}^{2-}$ foi determi nada pel o método turbi dimétrico, eos resultados mostraram queo processo de conversão foi adequado. A obtenção do gás $\mathrm{SO}_{2}$ foi por decomposiçãotérmica do $\mathrm{BaSO}_{4}$ em uma linha devácuoa $900{ }^{\circ} \mathrm{C}$, em presença de $\mathrm{NaPO}_{3}$. A determi nação isotópica doS (\% em átomos de ${ }^{34} \mathrm{~S}$ ) foi realizada em um espectrômetro demassa (I RMS). Nestetrabal ho, a utilização de material marcado $\left(\mathrm{K}_{2}{ }^{34} \mathrm{SO}_{4}\right)$ teve como propósito validar o método para determinação isotópica do S; os resultados obtidos foram exatos e precisos, mostrando a viabilidadedo método proposto.
\end{abstract}

Termos de indexação: preparo de amostras, amostras de sol o, di luição isotópica, isótopos estáveis, 34 S.

\section{INTRODUCTION}

Sulphur is present in the soil in two basic forms; inorganic and organic S. In the inorganic form (sulphateS), S is availablefor plant uptake, but organic S accounts for $95 \%$ of thetotal sul phur in most soils. This is due to the close relation of organic $S$ with organic $\mathrm{C}$ and total N. Organic sulfur has two forms: organic S that is not bonded directly to C, consisting largely of $\mathrm{S}$ in the form of ester sulfates (organic sulfates containing C-O-S linkages) and organic S that is directly bonded to C (C-S), consisting largely of S in the form of S-containing amino acids, such as methionine and cysteine (Tabatabai, 1982; Freney, 1986; Havlin et al., 2005).

The method for $\mathrm{S}$ isotopic determination in soil samples involves several steps such as: converting all S-organic to sulfate $\left(\mathrm{BaSO}_{4}\right)$; preparation and purification of $\mathrm{SO}_{2}(\mathrm{~g})$ in a high-vacuum system and isotopic analysis of S (atom \% or $\delta^{34} \mathrm{~S} \% d$ by isotoperatio mass spectrometry (IRMS).

The conversion of organic $S$ to sulphate by various methods was described el sewhere (Krouse et al., 1996; Menegário et al., 1998; Rossete et al., 2008a), but the complexity of the organic matrix of the soil hampers the procedures of sample preparation for isotope analysis of S. M ost methods employed for sulfur oxidation in soil analysis involve wet or dry-ash oxidation (Rossete et al., 2008a). I n comparison with wet oxidation, digestion by nitric and perchloric acids is more frequently used, but requires safety measures against explosion and fire, aside from possible material Iosses, that can make the method unserviceable (Tabatabai, 1982).

The conventional method for oxidation of organic $\mathrm{S}$ to sulphate uses nitric acid and liquid bromine (Krouse \& Tabatabai, 1986; Krouseet al., 1996). This method is seldom recommended due to the risks of $\mathrm{Br}_{2}$ and toxic waste generation. The biological action of bromine in its liquid and gaseous states is highly noxious. Bromine causes strong irritation in eyes and skin, necroses, and inflammation of the breathing system.
In the preparation of $\mathrm{SO}_{2}$, a gas suited for studies on isotope determination by isotope-ratio mass spectrometry (Hamilton et al., 1991; Bendassolli et al., 1997), procedures of combustion, purification and preparation of the gas in vacuum system were used, avoiding isotopic fractionation of the sample (F ritz et al., 1974; Schoenau \& Bettany, 1988; Krouse et al., 1996).

Of the known isotopes of Sulfur, four are stable: ${ }^{32} \mathrm{~S},{ }^{33} \mathrm{~S},{ }^{34} \mathrm{~S}$, and ${ }^{36} \mathrm{~S}$, with natural abundances of 95.02; $0.75 ; 4.21$ and 0.02 atom \%, respectively (K rouse et al., 1996). Some researchers used the radioisotope ${ }^{35} \mathrm{~S}$ as tracer, especially in studies involving the dynamics of this nutrient in the soilplant system (Lal \& Dravid, 1990; Arora et al., 1990; Sharma \& Kamath, 1991; Bansal \& Mortiramani, 1993; Patnaik \& Santhe, 1993; Fitzgerald et al., 1999). However, compounds label ed with the stable isotope ${ }^{34} \mathrm{~S}$ have some advantages over the radioisotope, because the experiments are not related to the decay rateand if there is no exposure to radiation, no safety measures against radiation are required. The first studies using the ${ }^{34} \mathrm{~S}$ isotopic tracer were devel oped by Hamilton et al. (1991) and Awonaike et al. (1993) and in Brazil by Trivelin et al. (2002), who used sulphate- ${ }^{34} \mathrm{~S}$ in studies on sulphur in soil under rice and sunn hemp (Crotalaria juncea).

In a study addressing the isolation of the ${ }^{34} \mathrm{~S}$ isotope, Bendassolli et al. (1997) wereableto produce a series of different labeled compounds, e.g., ammonium sulfate, gypsum, potassium sulfate, and single superphosphate (Maximo et al ., 2005; Rossete et al., 2006, 2008b). Recently, the stable isotope ${ }^{34} \mathrm{~S}$ has been used tostudy sul phur uptakeand distribution in wheat plants (Zhao et al., 2001). These compounds motivate the use of the isotopic technique ${ }^{\left({ }^{34} \mathrm{~S}\right)}$ in many research studies, and shed light on a number of aspects related to isotope determination (sample preparation) (Carneiro, et al., 2008).

In this context, the objective of this work was to devel op a method for isotopic determination of S (atom $\%{ }^{34} \mathrm{~S}$ ) in different soils by I sotope ratio mass spectrometry (IRMS). The proposed method was validated by the use of labeled material $\left(\mathrm{K}_{2}{ }^{34} \mathrm{SO}_{4}\right)$. 


\section{MATERIAL AND METHODS}

\section{Equipment}

The I sotope Ratio Mass Spectrometer (IRMS), model $\mathrm{CH} 4$ ATLAS-MAT, is equipped with a molecular-flow admission system and Faraday-cup ion collector. The analytical system comprises a vacuum system with a mechanic vacuum pump, a diffuser vacuum pump, an active vacuum measurer and a vacuum filament sensor.

\section{Sample preparation and total sulfur determination in soil}

Different soil types with sandy and clayey texture, were used to evaluate the total $\mathrm{S}$ determination method (Rossete et al., 2008a). Soil samples were collected from the surface horizon $(0-20 \mathrm{~cm})$, at different locations in theState of São Paulo. The soils were classified according to the Brazilian Soils Classification System (Embrapa, 2006).

OrganicS in soil samples was oxidized to sulphate to determineS by dry-ash oxidation, using $\mathrm{NaHCO}_{3}$ (alkaline medium) and $\mathrm{Ag}_{2} \mathrm{O}$ as oxidizing agents (Rossete et al., 2008a). The soil sample (5.0 g) and $\mathrm{NaHCO} / \mathrm{Ag}_{2} \mathrm{O}$ mixture (2.0/0.2 g) were mixed in a porcelain mortar. Thereafter, the material was combusted at $550^{\circ} \mathrm{C}$ in a mufflefor $8 \mathrm{~h}$, inducing the oxidation of organic $S$ to sulphate. To establish the analytical calibration curve for 2.5; 5; 10; 15; and 20 $\mathrm{mg} \mathrm{L}^{-1} \mathrm{~S}-\mathrm{SO}_{4}^{-2}$, the proportional quantity of $\mathrm{NaHCO}_{3} /$ $\mathrm{Ag}_{2} \mathrm{O}$ mixturewas burned under thesameconditions as the soil. Then, the samples were cooled to room temperature and the resulting sulphate was solubilized in $30 \mathrm{~mL}$ of $0.15 \%(\mathrm{w} / \mathrm{v}) \mathrm{CaCl}_{2}$ solution and $1.0 \mathrm{~g}$ of activated charcoal. All soil extraction solutions wereshaken on a horizontal circular shaker at $200 \mathrm{rpm}$ for $15 \mathrm{~min}$. Finally, $20 \mathrm{~mL}$ of $0.15 \%(\mathrm{w} / \mathrm{v})$ $\mathrm{CaCl}_{2}$ solution were added and the extract was filtered through cellulose ester filter (diameter $45 \mathrm{~mm}$, mesh $0.45 \mu \mathrm{m})$. The S-SO ${ }_{4}^{2-}$ concentration was then determined by turbidimetry (Tabatabai \& Bremner, 1970; Andrade et al., 1990; Cantarella \& Prochnow, 2001).

\section{Soil labeling procedure}

The labeled material $\left(\mathrm{K}_{2}{ }^{34} \mathrm{SO}_{4}\right)$ was used in this study to validate the proposed method. In experiments analyzing isotopic dilution, the diferente isotope values of the labeled material $\left(\mathrm{K}_{2}{ }^{34} \mathrm{SO}_{4}\right)$ were $6.15 \pm 0.07 ; 8.97 \pm 0.01 ; 12.51 \pm 0.01$ and $15.03 \pm 0.04$ atom $\%{ }^{34} \mathrm{~S}$. The label ed potassium sulphate $\left(\mathrm{K}_{2}{ }^{34} \mathrm{SO}_{4}\right)$ was produced at USP/CENA Stable I sotope Laboratory.

F or this purpose, $5.0 \mathrm{~g}$ of Nitossolo Vermelho eutroférrico (NVef) and $5.0 \mathrm{~g}$ of Argissolo Vermel hoAmarelo distrófico soil (AVAd), were mixed with approximately 700.0 and $400.0 \mu \mathrm{g}$ of $\mathrm{S}$ contained in thelabeled material $\left(\mathrm{K}_{2}{ }^{34} \mathrm{SO}_{4}\right)$, respectively.
Thetheoretical isotopic abundance $\left(A b_{t}\right)$ should be calculated by equation 1 . The value obtained for total $\mathrm{S}$ should represent the sum of total initial $\mathrm{S}\left(\mathrm{ST}_{0}\right)$ and ${ }^{34} \mathrm{~S}$. Based on the results obtained by the isotopic analysis $\left(A b_{\text {exp }}\right)$ after adding the label ed material; it was possible to evaluate the method for organic S oxidation (dry-ash) by applying equation 1. Using the values for experimental isotopicabundance $\left(A b_{\text {exp }}\right)$ and theoretical isotopic abundance $\left(A b_{t}\right)$, the analytical error can becalculated by:

$$
\begin{aligned}
& \left(\mathrm{m}_{0} \text { soil } * \mathrm{ST}_{0}\right) * A b_{0}+{ }^{34} \mathrm{~S}_{1} * A b_{1}= \\
& {\left[\left(\mathrm{m}_{0} \text { soil } * \mathrm{ST}_{0}\right)+{ }^{34} \mathrm{~S}_{\mathrm{I}}\right] * A b_{\mathrm{t}}}
\end{aligned}
$$

$\mathrm{m}_{0}$ soil =total $\mathrm{S}$ in the sample $(\mu \mathrm{gS}) ; \mathrm{ST}_{0}=$ total initial $\mathrm{S}\left(\mu \mathrm{g} \mathrm{g}^{-1}\right) ; \mathrm{Ab}_{0}=$ natural isotopicabundance of $\mathrm{S}$ (atom $\left.\%{ }^{34} \mathrm{~S}\right) ;{ }^{34} \mathrm{~S}_{1}=$ spiked amounts of $\mathrm{K}_{2}{ }^{34} \mathrm{SO}_{4}$-labeled material $\left(\mu \mathrm{g}^{34} \mathrm{~S}\right) ; A b_{1}=$ isotopic abundance of labeled material $\left(\mathrm{K}_{2}{ }^{34} \mathrm{SO}_{4}\right.$ (atom $\left.\%{ }^{34} \mathrm{~S}\right) ; \mathrm{Ab}_{\mathrm{t}}=$ theoretical isotopic abundance (atom $\%{ }^{34} \mathrm{~S}$ ).

\section{Sample preparation for isotopic determination of S (atom\% ${ }^{34} \mathbf{S}$ )}

Soil-extractable $\mathrm{SO}_{4}{ }^{2-}$ was acidified and subsequently precipitated as $\mathrm{BaSO}_{4}$ by adding $10 \mathrm{~mL}$ of $10.0 \%(\mathrm{w} / \mathrm{v}) \mathrm{BaCl}_{2} \cdot 2 \mathrm{H}_{2} \mathrm{O}$ solution under agitation. After this procedure, the precipitated $\mathrm{BaSO}_{4}$ was washed with deionized water and centrifuged at 2500 $\mathrm{rpm}$ for $5 \mathrm{~min}$. This procedure was repeated three times to eliminate impurities of $\mathrm{BaCl}_{2} \cdot 2 \mathrm{H}_{2} \mathrm{O}$ excess. Then the preci pitate was dried to constant weight at $60{ }^{\circ} \mathrm{C}$ and $5.0 \mathrm{mg} \mathrm{BaSO}_{4}$ precipitate was mixed with $15 \mathrm{mg} \mathrm{NaPO}$ (Halas \& Wolacewic, 1981). $\mathrm{NaPO}_{3}$ was obtained by burning $\mathrm{NaH}_{2} \mathrm{PO}_{4} \cdot \mathrm{H}_{2} \mathrm{O}$ in a muffle at $200{ }^{\circ} \mathrm{C}$ for $2 \mathrm{~h}$. This step is necessary to removethe structural water from the compound and to eliminate possible organic impurities.

For $\mathrm{SO}_{2}$ production, the $\mathrm{BaSO}_{4} / \mathrm{NaPO}_{3}$ mixture was placed in a quartz tube (QT) (length about 30 $\mathrm{cm}$ ). A copper metal ring (about $2 \mathrm{~g}$ ) and quartz wool was always placed in the tube approximately $2 \mathrm{~cm}$ abovethemixture (sample/reagents). Copper is used to retain oxides formed during combustion and to convert possible $\mathrm{SO}_{3}$ into $\mathrm{SO}_{2}$, avoiding isotopic fractionation (Rafter, 1957; Yanagisawa \& Sakal, 1983). N ext, the QT was connected to a vacuum system by mechanic (MP) and diffuser (DP) pumps. A cylinder with dry ice/ethanol $\left(-70^{\circ} \mathrm{C}\right)$ and another with liquid $\mathrm{N}\left(-196^{\circ} \mathrm{C}\right)$ were introduced around the traps $\operatorname{Tr}_{1}$ and $T r_{2}$, respectively, which were used to purify and separate the gases $\left(\mathrm{SO}_{2}, \mathrm{~N}_{2}, \mathrm{CO}\right)$ in the vacuum system. Thetraps $\mathrm{Tr}_{1}$ and $\mathrm{Tr}_{2}$ were designed to trap vapors of water and $\mathrm{SO}_{2}$, respectively, formed during combustion. The vacuum system configuration was based on themethod devel oped by Bailey \& Smith (1972) (Figure 1).

In the next step, the MF heated to $900{ }^{\circ} \mathrm{C}$ was shifted upwards to the QT, where it was maintained for $10 \mathrm{~min}$ for the combustion of $\mathrm{BaSO}_{4}$ and further $\mathrm{SO}_{2}$ gas formation (Equation 2). 
$\mathrm{BaSO}_{4}+\mathrm{NaPO}_{3} \rightarrow \mathrm{NaBaPO}_{4}+\mathrm{SO}_{2(\mathrm{~g})}+1 / 2 \mathrm{O}_{2(\mathrm{~g})}$

Depending on the conditions $\left(\mathrm{O}_{2}\right.$ partial pressure), $\mathrm{SO}_{3}$ gas could be produced, which is undesirable, since it could cause isotopic fractionation in analysis. Equations 3 and 4 show the conversion of $\mathrm{SO}_{3}$ to $\mathrm{SO}_{2}$ by reduced copper introduction.

$$
\begin{gathered}
\mathrm{SO}_{2(\mathrm{~g})}+1 / 2 \mathrm{O}_{2(\mathrm{~g})} \rightleftharpoons \mathrm{SO}_{3(\mathrm{~g})} \\
\mathrm{SO}_{3(\mathrm{~g})}+\mathrm{Cu} \stackrel{\mathrm{o}}{\rightarrow} \mathrm{SO}_{2(\mathrm{~g})}+\mathrm{CuO}
\end{gathered}
$$

The $\mathrm{SO}_{2}$ formed after combustion was transferred into the stock flask (B) by replacing the bottle containingliquid $\mathrm{N}_{2}$ from trap $\mathrm{Tr}_{2}$ by the stock sample tube (ST). N ext, the ST containing the $\mathrm{SO}_{2}$ was transferred to the mass spectrometer admission system and the isotopic abundance of S (atom $\%{ }^{34} \mathrm{~S}$ ) was determined.

\section{I sotopic determination of (atom $\%{ }^{34} \mathbf{S}$ )}

The ${ }^{34} \mathrm{~S}$ isotope was determined (in atom \%) in the mass spectrometer (Bendassolli et al., 1997). The analysis based on isotopicratios or atom \% (abundance) of light elements is frequently carried out using properly purified gaseous samples. The proposed method involved procedures for chemical transformation in order to eliminategas interferences, and the combustion process for $\mathrm{SO}_{2}$ production was carried out in a vacuum system to avoid interferences of atmospheric gases.

Theintensities of the ion peaks of the species $\mathrm{SO}_{2}{ }^{+}$ and $\mathrm{SO}^{+}$were high and both could be used for the determination of isotopicS. Therefore, it was decided to work with $\mathrm{SO}^{+}$species for having a lower number of combinations between $\mathrm{S}$ and $\mathrm{O}$ elements. For SO molecular species, ion currents appear at $\mathrm{m} / \mathrm{z} 48$ (32 $\left.{ }^{16} \mathrm{O}\right) ; 49$ (32 $\mathrm{S}^{17} \mathrm{O}$ and $\left.{ }^{33} \mathrm{~S}^{16} \mathrm{O}\right) ; 50\left({ }^{32} \mathrm{~S}^{18} \mathrm{O} ;{ }^{33} \mathrm{~S}^{17} \mathrm{O}\right.$ and $\left.{ }^{44} \mathrm{~S}^{16} \mathrm{O}\right) ; 51$ (33 $\mathrm{S}^{18} \mathrm{O}$ and $\left.{ }^{34} \mathrm{~S}^{17} \mathrm{O}\right) ; 52\left({ }^{34} \mathrm{~S}^{18} \mathrm{O}\right.$ and $\left.{ }^{36} \mathrm{~S}^{16} \mathrm{O}\right) ; 53\left({ }^{36} \mathrm{~S}^{17} \mathrm{O}\right)$ and $54\left({ }^{36} \mathrm{~S}^{18} \mathrm{O}\right)$. For analysis, the

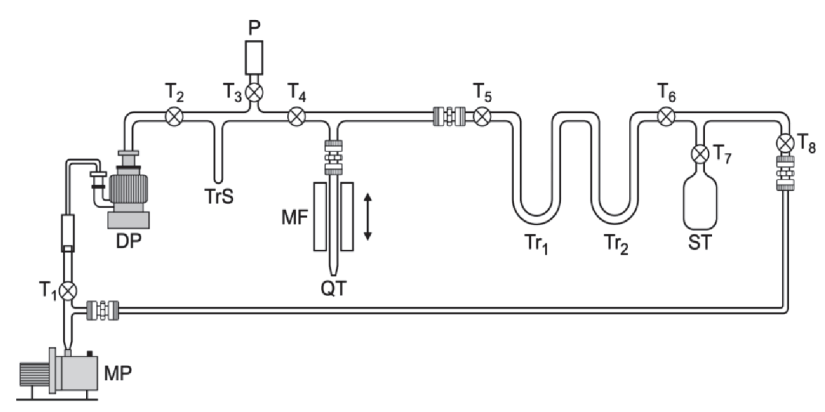

Figure 1. Vacuum system for $\mathrm{SO}_{2}$ production and purification. QT = quartz tube; MF = movable furnace $\left(900^{\circ} \mathrm{C}\right) ; \mathrm{Tr}_{1}=$ trap with dry ice / ethanol $\left(-70^{\circ} \mathrm{C}\right) ; \mathrm{Tr}_{2}=$ trap with liquid nitrogen $\left(-196^{\circ} \mathrm{C}\right)$; ST: stock sample tube; $P=$ Pirani vacuum gauge filament sensor (E dwards); TrS = security trap with liquid nitrogen $\left(-196{ }^{\circ} \mathrm{C}\right)$; DP = diffusion pump (high-vacuum); MP = mechanical pump; $\mathbf{T}_{1}$ to $\mathbf{T}_{8}=$ Taps mass spectrometer worked with an admission system heated to $70{ }^{\circ} \mathrm{C}$ due to the polar nature of the $\mathrm{SO}_{2}$ and $\mathrm{SO}$ molecules, thus avoiding a memory effect. A cryogenic trap containing dry ice and ethanol $\left(-70^{\circ} \mathrm{C}\right)$ was placed below the mass spectrometer admission system to retain undesirable residual water from samples. The tests were carried out with five replications, in a completely randomized design, in factorial combination. The means were subjected to statistical analysis (Tukey $5 \%$ ) (SAS, 2008).

\section{RESULTS AND DISCUSSION}

In experiments related to the use of metallic copper in the quartz tube, it was observed that $2 \mathrm{~g}$ of material was necessary toavoid undesired oxideformation $(\mathrm{BaO}$ and $\mathrm{CaO}$ ) in the vacuum system. In the assessment of the time required for $\mathrm{SO}_{2}$ formation in the highvacuum system, the oven-burning time of $\mathrm{BaSO}_{4}$ varied from 4 to $10 \mathrm{~min}$. Results indicated that combustion was complete after $10 \mathrm{~min}$, and no alteration of the signal was observed after longer periods. Therefore, $10 \mathrm{~min}$ was determined for this step, for improving parameters related to volatile compound formation. For the isotopic determination of $S$, the peaks in the mass spectrum were related to the species $\mathrm{SO}^{+}$(Figure 2 ).

Results for isotopic determination of ${ }^{34} \mathrm{~S}$ in $\mathrm{SO}_{2}$ samples obtained applying the $\mathrm{BaSO}_{4}$ p.a. (natural abundance) was $4.23 \pm 0.02$ atom $\%{ }^{34} \mathrm{~S}$. The corresponding values of samples with natural variation are in agreement with the expected values, demonstrating that the process for $\mathrm{SO}_{2}$ production in presence of $\mathrm{NaPO}_{3}$ and the method for isotopic determination of $\mathrm{S}$ in the mass spectrometer were suitable. Validation of the proposed method was

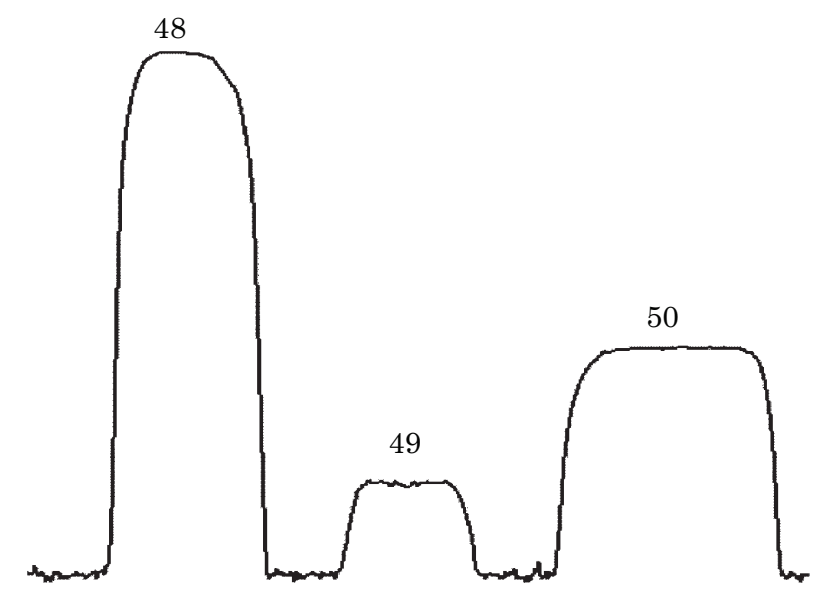

Figure 2. Mass spectrum related to SO+ species by IR MS. Peaks were measured at m/e 48 (32S160), 49 (32S17O and 33S16O), 50 (32S180, 33S170 and 34 (160). 
accomplished by analysis of different soil types classified according to the Brazilian System of Soils Classification (Embrapa, 2006). The initial amount of $S\left(\mu \mathrm{g} \mathrm{g}^{-1}\right.$ of S) and isotopic abundance (atom\% of ${ }^{34} \mathrm{~S}$ ) was evaluated (Table 1).

The ${ }^{34} \mathrm{~S}$ (atom \%) in soil samples was determined in three replications and in the isotopic results evaluation the natural variation from -30 to $+30 \%$ o was taken into account (Krouse \& Tabatabai, 1986). These natural variation values correspond to a variation of $4.15-4.38$ atom $\%{ }^{34} \mathrm{~S}$. The analytical precision of the mass spectrometer is approximately $1 \%$. After addition of 700.0 and $400.0 \mu \mathrm{g}$ of $\mathrm{S}$ in labeled $\mathrm{K}_{2}{ }^{34} \mathrm{SO}_{4}$ to $5 \mathrm{~g}$ of Nitossolo Vermel ho eutroférrico (NVef) and Argissolo Vermelho-Amarelo (AVAd), respectively, the values for experimental isotopic abundance $\left(A b_{\text {exp }}\right)$ and theoretical isotopic abundance $\left(A b_{t}\right)$ were determined (Table 2$)$. The values of $A b_{t}$ and $A b_{\text {exp }}$ were obtained by equation 1 and by IRMS, respectively.

Results indicated nosignificant differencebetween experimental isotopic abundance $\left(A b_{\text {exp }}\right)$ and theoretical isotopic abundance $\left(A b_{t}\right)$ for the Argissolo Vermelho-Amarelo (Table 2). However, for the Nitossolo Vermel ho eutroférrico, the statistical analysis indicated significant differences $(p<0.05)$ when $\mathrm{K}_{2}{ }^{34} \mathrm{SO}_{4}$, labeled on 6.15 atom $\%{ }^{34} \mathrm{~S}$, was used.
Based on results obtained for $\mathrm{S}$ isotopic determination (atom $\%{ }^{34} \mathrm{~S}$ ) by using ${ }^{34} \mathrm{~S}$-labeled $\mathrm{K}_{2} \mathrm{SO}_{4}$, the analytical error was calculated as about $1.1 \%$. This result was considered low, considering the number of steps in the proposed method, and the complexity of theanalytical process.

\section{CONCLUSIONS}

1. The use of a high-vacuum system for conversion of $\mathrm{Ba}^{34} \mathrm{SO}_{4}$ to $\mathrm{SO}_{2}$ using $\mathrm{NaPO}_{3}$ and combustion is suitablefor the proposed method. Based on theresults obtained in the validation experiments (isotopic dilution), it was verified that dry oxidation is feasible for the conversion of organic S to sulphate.

2. Theresults obtained in isotopic determination of $\mathrm{S}$ by isotope-ratio mass spectrometry (IRMS) were precise and accurate, showing the viability of the proposed method.

\section{ACKNOWLEDGE ME NT}

Theauthors wish to thank FAPESP for the partial financial support and the fellowships.

Table 1. Total S and isotopic determination (atom $\% 345$ ) in soil samples

\begin{tabular}{|c|c|c|}
\hline Soil (1) & $\mathrm{ST}_{0}{ }^{(2)}$ & $A b_{0}{ }^{(3)}$ \\
\hline & $\mu g^{-1}$ & atom $\%{ }^{34} \mathrm{~S}$ \\
\hline Latossolo Vermelho eutroférrico (LVef) & $250.1 \pm 1.2$ & $4.43 \pm 0.01$ \\
\hline Neossolo Quartzarênico órtico (NQo) & $61.0 \pm 5.4$ & $4.41 \pm 0.02$ \\
\hline Nitossolo Vermelho eutroférrico (NVef) & $222.5 \pm 4.8$ & $4.41 \pm 0.01$ \\
\hline Latossolo Vermelho distrófico (LVd) & $167.7 \pm 3.5$ & $4.43 \pm 0.03$ \\
\hline Argissolo Vermelho-Amarelo distrófico (AVAd) & $135.6 \pm 2.2$ & $4.43 \pm 0.03$ \\
\hline Argissolo Vermelho distrófico (AVd) & $103.9 \pm 4.8$ & $4.45 \pm 0.02$ \\
\hline
\end{tabular}

${ }^{(1)}$ Brazilian Soils Classification System; ${ }^{(2)}$ Results of total initial S determined by turbidimetry; ${ }^{(3)}$ Results of isotopic $\mathrm{S}$ initial (natural abundance) determined by IRMS; \pm Relative standard deviations $(n=5)$.

Table 2. I sotopic determination of S (atom \% ${ }^{34 S}$ ) in soil samples with application of labeled $\mathrm{K}_{2}{ }^{34 \mathrm{SO}_{4}}$

\begin{tabular}{ccccc}
\hline Labeled $\mathbf{K}_{\mathbf{2}}{ }^{\mathbf{3 4}} \mathbf{S O}_{\mathbf{4}}$ & \multicolumn{2}{c}{ Nitossolo Vermelho eutroférrico (NVef) } & \multicolumn{2}{c}{ Argissolo Vermelho-Amarelo distrófico (AVAd) } \\
\hline & $\mathrm{A} \mathrm{b}_{\exp }$ & $\mathrm{Ab}$ & $\mathrm{Ab} \mathrm{b}_{\mathrm{exp}}$ & $\mathrm{Ab} \mathrm{b}_{\mathrm{t}}$ \\
6.15 & $5.21 \pm 0.03 \mathrm{a}$ & $5.08 \pm 0.01 \mathrm{~b}$ & $5.15 \pm 0.01 \mathrm{a}$ & $5.07 \pm 0.01 \mathrm{a}$ \\
8.97 & $6.25 \pm 0.02 \mathrm{a}$ & $6.17 \pm 0.02 \mathrm{a}$ & $6.06 \pm 0.03 \mathrm{a}$ & $6.11 \pm 0.02 \mathrm{a}$ \\
12.51 & $7.64 \pm 0.08 \mathrm{a}$ & $7.54 \pm 0.03 \mathrm{a}$ & $7.49 \pm 0.06 \mathrm{a}$ & $7.43 \pm 0.03 \mathrm{a}$ \\
15.03 & $8.55 \pm 0.07 \mathrm{a}$ & $8.51 \pm 0.04 \mathrm{a}$ & $8.29 \pm 0.08 \mathrm{a}$ & $8.36 \pm 0.03 \mathrm{a}$ \\
\hline
\end{tabular}

Results represent the $\mathrm{S}$ isotopic abundance in the soil samples, determined by mass spectrometry. Means followed by the same letter in the rows did not differ statistically (Tukey test, $\mathrm{p}<0.05, \mathrm{n}=5$ ); \pm Relative standard deviations. 


\section{LITERATURE CITED}

ANDRADE, J.C.; FRIGUETTO, S.R.; BACCAN, N.; CANTARELLA, H. \& BATAGLIA, O.C. Determinação turbidimétrica de sulfato em solos mediante análise por injeção em fluxo. R. Bras. Ci. Solo, 14:119-124, 1990.

ARORA, B.R.; HUNDAL, H.S. \& SEKHON, G.S. Utilization of fertilizer sulphur by oat (Avena sativa L.) in different soils of Ludhiana. J . Nuclear Agric. Biol., 19:92-96, 1990.

AWONAIKE, K.O.; DANSO, S.K.A. \& ZAPATA, F. The use of a double isotope (N-15 and S-34) labeling technique to assess the suitability of various reference crops for estimating nitrogen-fixation in Gliricidia sepium and Leucaena leucocephala. Plant Soil, 155/156:325-328, 1993.

BAILEY, S.A. \& SMITH, I.W. I mproved method for the preparation of sulfur dioxide from barium sulfate for isotope ratio studies. Anal. Chem., 44:1542-1543, 1972.

BANSAL, K.N. \& MOTIRAMANI, D.P. Uptake of native and applied sulphur by soybean in vertisols of Madhya Pradesh. J . Nuclear Agric. Biol., 22:42-46, 1993.

BENDASSOLLI, J.A.; TRIVELIN, P.C.O. \& CARNEIRO J UNIOR, F.C. Stable sulfur isotope fractionation by anion exchange chromatography; production of compounds enriched in ${ }^{34}$ S. J . Braz. Chem. Soc., 8:13-17, 1997.

CANTARELLA, H. \& PROCHNOW, L.I. Determinação de sulfato em solos. In: RAIJ, B.van; ANDRADE, J.C.; CANTARELLA, H. \& QUAGGIO,J .A., eds. Análise química para avaliação da fertilidade de solos tropicais. Campinas, Instituto Agronômico de Campinas, 2001. p.225-230.

CARNEIRO, J.M.T.; ROSSETE, A.L.M. \& BENDASSOLLI, J .A. I sotopic determination of silicon by mass spectrometry in plants and soils labeled with ${ }^{30} \mathrm{Si}$. Anal. Letters, 41:16401647, 2008.

EMPRESA BRASILEIRA DE PESQUISA AGROPECUÁRIA EMBRAPA. Centro Nacional de Pesquisa de Solos. Sistema brasileiro de classificação de solo. Rio de J aneiro, 2006. p.306.

FITZGERALD, M.A.; UGALDE, T.D. \& ANDERSON, J.W. Sulfur nutrition changes the sources of $S$ in vegetative tissues of wheat during generative growth. J. Exp. Bot., 50:499-508, 1999.

FRENEY, J.R. Forms and reactions of organic sulfur compounds in soils. In: TABATABAI, M.A., ed. Sulfur in agriculture. Madison, American Society of Agronomy. 1986, p.207-232. (Agronomy Monograph, 27).

FRITZ, P; DRIMMIE, R.J . \& NOWICKI, V.K. Preparation of sulfur dioxide for mass spectrometer analyses by combustion of sulfides with copper oxide. Anal. Chem., 46:164-166, 1974.

HALAS, S. \& WOLACEWICZ, W. Direct extraction of sulfur dioxide from sulfates for isotopic analysis. Anal. Chem., 53:686-689, 1981

HAMILTON, S.D.; CHALK, P.M.; UNDOVICH, M.J . \& SMITH, C.J. The measurement of fertilizer-S uptake by plants using radioactive and stable isotopes. Appl. Radiat. I sot., 42:1099-1101, 1991.
HAVLIN, J.L.; BEATON, J .D.; TISDALE, S.L. \& NELSON, W.L. Soil fertility and fertilizers. 7th ed. Upper Saddle River: Pearson Education, 2005. 515p.

KROUSE, H.R.; BERNHARD, M. \& SCHOENAU, J.J. Applications of stable isotopes techniques to soil sulphur cycling. In: BOUTTON, T.W. \& YAMASAKI, S., eds. Mass spectrometry of soil. New York, Marcel Dekker, 1996. p.246-285.

KROUSE, H.R. \& TABATABAI, M.A. Stable sulphur isotopes. In: TABATABAI, M.A., ed. Sulphur in agriculture. Madison, America Society of Agronomy, 1986. p.169-205.

LAL, K. \& DRAVID, M.S. Sulphur utilization by mustard as influenced by $\mathrm{P}, \mathrm{S}, \mathrm{K}_{2} \mathrm{SiO}_{3}$ and $\mathrm{FYM}$ in Tupic Ustipsamment. J . Nuclear Agric. Biol., 9:87-91, 1990.

MAXIMO, E.; BENDASSOLLI, J.A.; TRIVELIN, P.C.O.; ROSSETE, A.L.R.M.; OLIVEIRA, C.R. \& PRESTE, C.V. Produção de sulfato de amônio duplamente marcado com os isótopos estáveis ${ }^{15} \mathrm{~N}$ e ${ }^{34} \mathrm{~S}$. Quím. Nova, 28:211-216, 2005.

MENEGÁRIO, A.A.; GINÉ, M.F.; BENDASSOLLI, J .A.; BELLATO, A.C.S. \& TRIVELIN, P.C.O. Sulfur isotope ratio $\left({ }^{34} \mathrm{~S}:{ }^{32} \mathrm{~S}\right)$ measurements in plant material by inductively coupled plasma mass spectrometry. J . Anal. Atomic Spectrom., 13:1065-1067, 1998.

PATNAIK, M.C. \& SANTHE, A. Influence of N, P, $\mathrm{CaSO}_{4}$ on utilization of sulphur by rice in red sandy loam soil. J. Nuclear Agric. Biol., 22:75-79, 1993.

RAFTER, T.A. The preparation of sulfur dioxide for mass spectrometer examination. J. Sci. Technol., 38:849-857, 1957.

ROSSETE, A.L.R.M.; BENDASSOLLI, J .A.; MAXIMO, E.; SANT ANA FILHO, C.R. \& IGNOTO, R.F. Production of ${ }^{34} \mathrm{~S}$ labeled gypsum $\left(\mathrm{Ca}^{34} \mathrm{SO}_{4} \cdot 2 \mathrm{H}_{2} \mathrm{O}\right)$. Sci. Agric., 63:399404, 2006.

ROSSETE, A.L.R.M.; BENDASSOLLI, J.A. \& TRIVELIN P.C.O. Organic sulfur oxidation to sulfate in soil samples for total sulfur determination by turbidimetry R. Bras. Ci. Solo, 32:2547-2553, 2008a.

ROSSETE, A.L.R.M.; CARNEIRO, J .M.T.; BENDASSOLLI, J.A.; TAVARES, C.R.O. \& SANT ANA FILHO, C.R. Production of single superphosphate label ed with ${ }^{34} \mathrm{~S}$. Sci. Agric., 65:91-94, 2008b.

SAS I nstitute Inc. The SAS system [programa de computador]. version 9.2. Cary, 2008.

SCHOENAU, J J . \& BETTANY, J .R. A method for determining sulfur-34 abundance in soil and plant sulfur fractions. Soil Sci. Soc. Am. J ., 52:297-300, 1988.

SHARMA, V.K. \& KAMATH, M.B. Effect of sulphur, phosphorus and calcium on sulphur utilization by mustard (Brassica juncea L.) and Pea (Pissum sativum L.). J . Nuclear Agric. Biol., 20:123-127, 1991.

TABATABAI, M.A. \& BREMNER, J .M. A simple turbidimetric method of determining total sulfur in plant materials. Agron. J ., 62:805-806, 1970. 
TABATABAI, M.A. Sulfur. In: PAGE, R.L.; MILLER, R.H. \& KEENEY, D.R., eds. Methods of soil analysis: Chemical and microbiological properties. 2.ed. Madison, American Society of Agronomy, 1982. Part 1. p.501-538.

TRIVELIN, P.C.O.; BENDASSOLLI, J.A.; CARNEIRO J UNIOR, F. \& MUROAKA, T. Sulfur utilization by rice and Crotalaria juncea from sulfate - ${ }^{34} \mathrm{~S}$ applied to the soil. Sci. Agric., 59:205-207, 2002.
YANAGISAWA, F. \& SAKAL, H. Thermal decomposition of barium sulfate-vanadium pentaoxide-silica glass mixtures for preparation of sulfur dioxide in sulfur isotope ratio measurements. Anal. Chem., 55:985-987, 1983.

ZHAO, F.J .; VERKAMPEN, K.C.J .; BIRDSEY, M.; BLAKEKALFF, M.M.A. \& McGRATH, S.P. Use of the enriched stable isotope ${ }^{34} \mathrm{~S}$ to study sulfur uptake and distribution in wheat. J. Plant Nutr., 24:1551-1560, 2001. 